\title{
PERANCANGAN ENTERPRISE ARCHITECTURE PADA PENGELOLAAN SURAT MENGGUNAKAN STANDAR FEAF
}

\author{
Sudin Saepudin ${ }^{1)}$, Salsa Tini Kareksi ${ }^{2)}$ \\ ${ }^{1.2}$ Program Studi Sistem Informasi, Universitas Nusa Putra \\ ${ }^{1.2}$ Jl.Raya Cibatu Cisaat No.21, Cibolang Kaler, Kec.Cisaat, Sukabumi \\ Email: ${ }^{1}$ sudin.sapudin@nusaputra.ac.id 22salsa.tini_si17@nusaputra.ac.id
}

\begin{abstract}
At the Sukabumi District Transportation Office, letter management activities are carried out in a semi-computerized manner, namely using an agenda book and the Microsoft Excel application, however, although letter management activities are computerized, there are several obstacles, namely frequent errors in letter data collection and loss of letter data. . Broadly speaking, the loss of letter data occurs in incoming mail data in 2019, the loss of incoming mail data reaches $50 \%$, while errors in the data collection of letters occur in outgoing mail data, errors in data collection almost occur every year and reach 10-40\% so that it can affect making reports on the number of letters. Because of these various problems, the researcher will design an enterprise architecture for letter management using the FEAF (Federal Enterprise Architecture Framework) standard in the Sukabumi Dis-trict Transportation Service. This research will produce a framework (blueprint) which is expected to be a source of reference in implementation and to facilitate the management of incoming and outgoing mail by considering aspects of business, information, applications and technology.
\end{abstract}

Keywords: Enterprise Architecture, FEAF (Federal Enterprise Architecture Framework), Blueprint.

\begin{abstract}
Abstrak
Di Kantor Dinas Perhubungan Kab.Sukabumi kegiatan pengelolaan surat dilakukan dengan cara semi komputerisasi yaitu menggunakan buku agenda dan aplikasi Microsoft Excel, akan tetapi walaupun kegiatan pengelolaan surat sudah terkomputerisasi namun ada beberapa hal yang menjadi hambatan yaitu sering terjadi kesalahan dalam pendataan surat dan kehilangan data surat. Secara garis besar kehilangan data surat terjadi pada data surat masuk tahun 2019, hilangnya data surat masuk mencapai $50 \%$ sedangkan kesalahan dalam pendataan surat itu terjadi pada data surat keluar, kesalahan dalam pendataan hampir terjadi setiap tahunnya dan mencapai $10-40 \%$ sehingga dapat berpengaruh terhadap pembuatan laporan jumlah surat. Karena berbagai permasalahan tersebut maka peneliti akan membuat perancangan enterprise architecture pada pengelolaan surat menggunakan standar FEAF (Federal Enterprise Architecture Framework) di Dinas Perhubungan Kab.Sukabumi. Penelitian tersebut akan menghasilkan berupa kerangka kerja ( blueprint) yang diharapkan dapat menjadi sumber acuan dalam implementasi dan dapat mempermudah dalam kegiatan pengelolaan surat masuk dan surat keluar dengan mempertimbangkan aspek bisnis,informasi,aplikasi dan teknologi.
\end{abstract}

Kata kunci: Enterprise Architecture, FEAF ( Federal Enterprise Architecture Framework.), Blueprint

\section{Pendahuluan}

Perkembangan teknologi informasi yang pesat telah sangat mempengaruhi berbagai bidang yang menggunakan sistem informasi (SI) dan teknologi informasi (TI), salah satunya adalah pemanfaatan desain bisnis besar yang menjadi dasar bagi organisasi / instansi dalam menerapkan perencanaan strategi yang terstruktur dan sistematis. Teknologi Informasi sangat penting. untuk mendorong pengaturan inovasi mendasar sebagai tahap awal dalam mengidentifikasi sistem dan layanan yang baik untuk memenuhi kebutuhan pengguna.[1] salah satunya dalam proses pengelolaan surat, surat adalah perangkat khusus untuk meneruskan data yang disusun dimulai dengan satu pengumpulan lalu ke pengumpulan berikutnya. Sebuah surat seharusnya menjadi selembar kertas yang ditulis atas nama individu penulis, atau untuk kepentingan situasinya dalam pergaulan, yang diarahkan ke lokasi tertentu yang berisi materi korespondensi. Materi korespondensi surat adalah penjelasan yang memuat pilihan, artikulasi, pemberitahuan dan tuntutan.

Di Dinas Perhubungan Kab.Sukabumi kegiatan pengelolaan surat menyurat dilakukan secara semi komputerisasi menggunakan buku agenda dan aplikasi Microsoft Excel, akan tetapi walaupun sistem pengelolaan surat sudah terkomputerisasi namun ada beberapa hal yang menjadi hambatan yaitu sering terjadi kesalahan dalam pendataan surat, lambat dalam pencarian surat, kehilangan data surat dan tidak adanya duplikasi surat. 


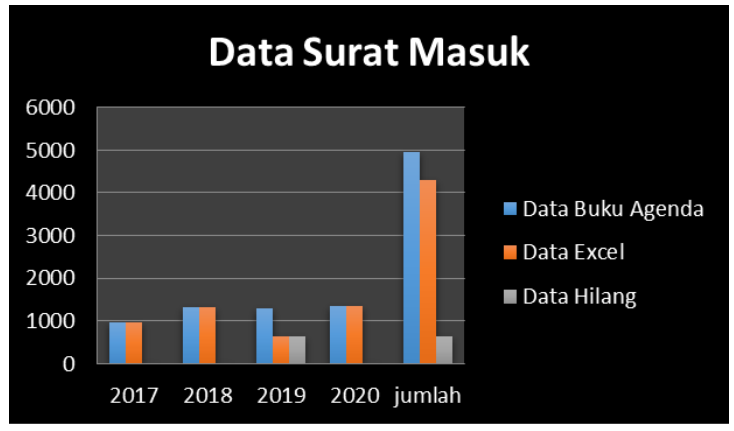

Gambar 1. Grafik Data Surat Masuk

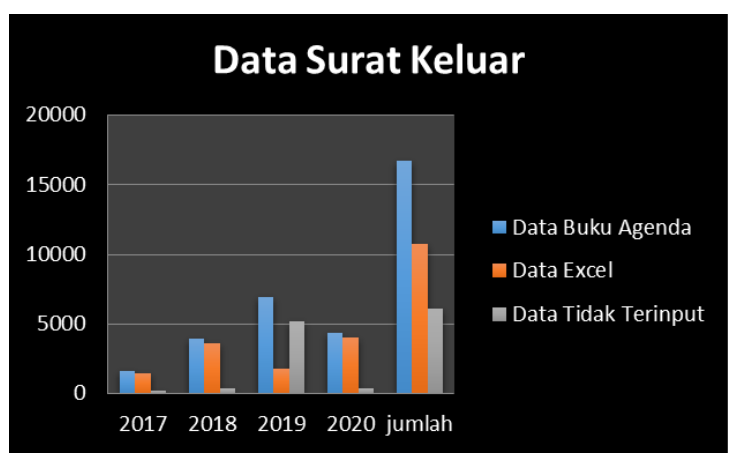

Gambar 2. Grafik Data Surat Keluar

Secara garis besar dapat dilihat dari grafik data surat masuk pada tahun 2019 terjadinya penurunan hampir $50 \%$ dikarenakan data surat masuk hilang. sedangkan dilihat dari grafik data surat keluar itu terjadi kesalahan dalam pendataan surat, banyak nya data surat keluar yang tidak terinput ke microsoft excel hampir setiap tahun nya terjadi dan mencapai $10-40 \%$ sehingga menyebabkan ketidak sesuaian antara jumlah data surat keluar yang di input di excel dan jumlah data surat keluar yang dicatat di buku agenda sehingga itu dapat berpengaruh terhadap pembuatan laporan jumlah data surat yang dilakukan setiap tahunnya

Karena berbagai permasalahan tersebut maka Dinas Perhubungan Kab.Sukabumi perlu melaksanakan suatu rancangan enterprise architecture untuk dapat melakukan perencanaan dan pengelolaan dalam proses pengelolaan surat. Untuk mencapai tujuan tersebut maka dibuatlah analisis perancangan EA menggunakan metode FEAF yang terdiri atas empat level dan matriks FEAF. Berdasarkan pernyataan diatas maka peneliti akan membuat perancangan arsitektur enterprise pada pengelolaan surat menggunakan standar FEAF (Federal Enterprise Architecture Framework) di Dinas Perhubungan Kab.Sukabumi, yang dihasilkan dari penelitian ini yaitu berupa kerangka kerja ( blueprint ) yang diharapkan dapat menjadi sumber acuan dalam dalam mengimplementasikan sistem pengelolaan surat dan dapat mempermudah dalam kegiatan pengelolaan surat masuk dan surat keluar dengan mempertimbangkan aspek bisnis,informasi, aplikasi dan teknologi.

\subsection{Tahapan Penelitian}

\section{Metodologi Penelitian}

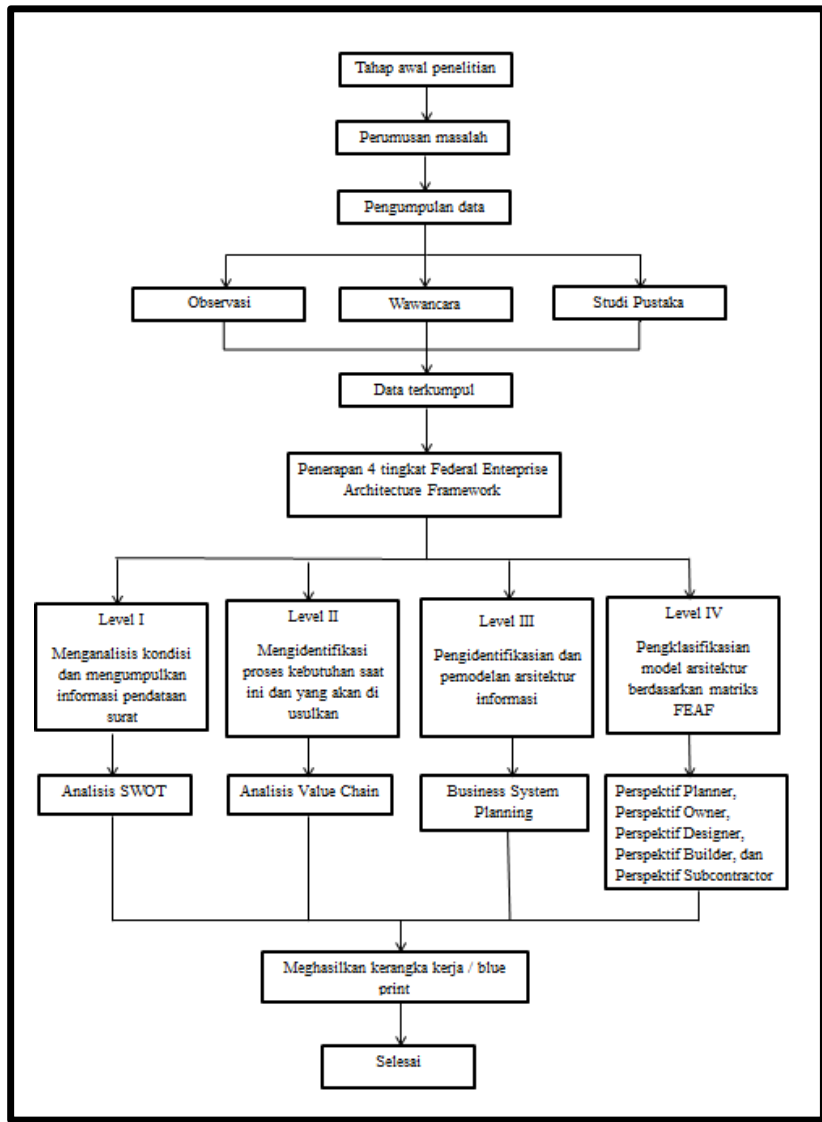

\subsection{Pengumpulan Data}

Gambar 3. Tahapan Penelitian

2.2.1 Observasi dilakukan untuk meninjau secara langsung aktivitas yang dilakukan di Dinas Perhubungan Kab.Sukabumi khususnya di bagian pengarsipan surat yang termasuk ke bagian Kasubag Umum dan Kepegawaian, yang beralamat di J1. Perintis Kemerdekaan Cikembang-Sukabumi.

2.2.2 Wawancara dilakukan bersamaan dengan kegiatan observasi, pewawancara mendatangi narasumber di lokasi tempat penelitian yaitu di Dinas Perhubungan Kab.Sukabumi. proses wawancara ditujukan kepada pihak yang sesuai dengan kebutuhan penelitian yaitu dengan bagian pengarsipan surat.

2.2.3 Studi Pustaka dilakukan untuk memperoleh data yang diidentifikasi dengan masalah yang akan direnungkan, penulis mengumpulkan informasi dari berbagai buku, buku harian, dan laporan yang berbeda untuk mendapatkan gambaran hipotetis dalam menjadikan laporan eksplorasi ini sebagai sumber perspektif.[2] Studi pustaka yang peneliti lakukan yaitu lebih banyak membaca jurnal-jurnal terkait dengan penelitian yang memanfaatkan media internet untuk mencari sumber referensi. 


\subsection{Metode Perencanaan Sistem Informasi}

Teknik penyusunan kerangka data dalam menangani surat ini menggunakan standar FEAF (Government Endeavour Design System). (FEAF) adalah sistem yang disajikan pada tahun 1999 oleh Government CIO Gathering. FEAF direncanakan untuk membuat EA di dalam Organisasi Pemerintah atau kerangka kerja yang melampaui berbagai batasan kantor. FEAF memberikan norma untuk membuat dan mengarsipkan teknik penggambaran daerah kebutuhan. FEAF cocok untuk menggambarkan rekayasa untuk pemerintah Pusat [3]. FEAF menciptakan empat tingkat Sistem Rekayasa Upaya Pemerintah. Setiap level memberikan pengaturan atau acuan untuk tahun berikutnya.. Empat tingkat Federal Enterprise Architecture Framework sebagai berikut :

1) FEAF Level I Tahap ini merupakan tahap penting dalam asosiasi FEAF karena merupakan siklus yang mendasari untuk menggambarkan rencana bisnis besar seperti apa yang dibutuhkan seperti yang ditunjukkan oleh prasyarat tujuan instansi/organisassi.[4] Pada tahap ini menggunakan analis SWOT (Strength, Weakness, Opportunities, Threat).

2) FEAF Level II Pada tahap ini, kebutuhan bisnis dan teknologi pendukung akan dikenali dan kemudian dikontraskan dengan inovasi pendukung yang diusulkan. [4] Tahap ini menggunakan analisis value Chain.

3) FEAF Level III Pada tahap ini membuat model desain bisnis, data, aplikasi dan teknologi akan dibuat berdasarkan identifikasi dan analisis di tahap sebelumnya, analis menggunakan Value Chain untuk pengelompokan berdasarkan teknologi untuk aktivitas bisnis utama dan teknologi pendukung. .[4] Level III membuat rekayasa data yang mendemonstrasikan sebagai garis besar kumpulan data yang akan digunakan untuk mewajibkan kerangka data yang akan kita konfigurasi sesuai kebutuhan dan tujuan organisasi. Pada tahap ini memanfaatkan perangkat BSP (Business System Planning).

4) FEAF Level IV Pada tahap ini mengenali detail objek dari setiap model arsitektur, khususnya data, aplikasi, dan teknologi yang memanfaatkan matriks FEAF. Matrik FEAF membagi empat model menjadi 5 sudut pandang, untuk lebih spesifik yaitu Perspektif planner, perspektif owner, perspektif designer, perspektif builder, dan perspektif subcontractor. [4]

- Perspective Planner memperjelas pandangan dan seberapa besar kerangka sistem akan dibangun. [5]

- Perspective Owner menggambarkan rencana bisnis dan menunjukkan entitas bisnis. Salah satunya adalah pembuatan model semantik dan activity diagram..[5]

- Perspective Designer memperjelas model kerangka data yang direncanakan harus fokus pada jenis data, aliran data dan kapasitas dalam ukuran bisnis. Salah satunya dengan membuat
ERD (Entity Relationship Diagram) dan desain jaringan yang diusulkan.[5]

- Perspective Builder menggambarkan model teknologi yang harus disesuaikan dengan model framework baik perangkat input/output dan teknologi pendukung lainnya.[5]

- Perspective Subcontractor memperjelas spesifikasi detail yang akan digunakan sebelum framework dijalankan, salah satunya dengan membuat DDL (Data Definition Language) dan struktur framework. [5]

\section{Hasil dan Pembahasan}

Berdasarkan kerangka kerja Federal Enterprise Architecture Framework (FEAF) yang dikerjakan berdasarkan 4 tingkatan dan matriks 5 x 3 yang dimiliki oleh FEAF. Adapun hasilnya sebagai berikut :

3.1. FEAF Level I, menggunakan alat bantu analisis SWOT. Adapun hasilnya sebagai berikut :

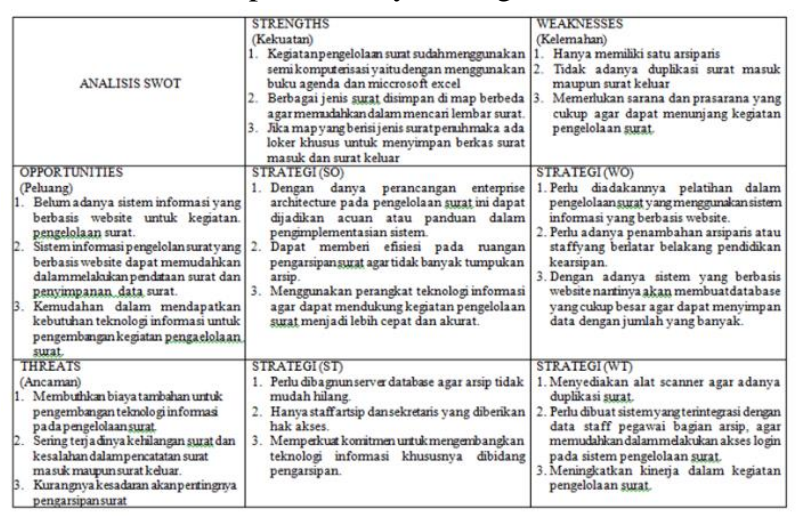

Tabel 1 Analisis Swot

3.2. FEAF Level II, Pada tahap ini menggunakan alat bantu Value Chain. Adapun hasil analisis value chain sebagai berikut

Gambar. 4. Value Chain

3.3. FEAF Level III, pada tahap ini menggunakan alat bantu teknik BSP (Business System Planning ). Adapun hasilnya sebagai berikut :

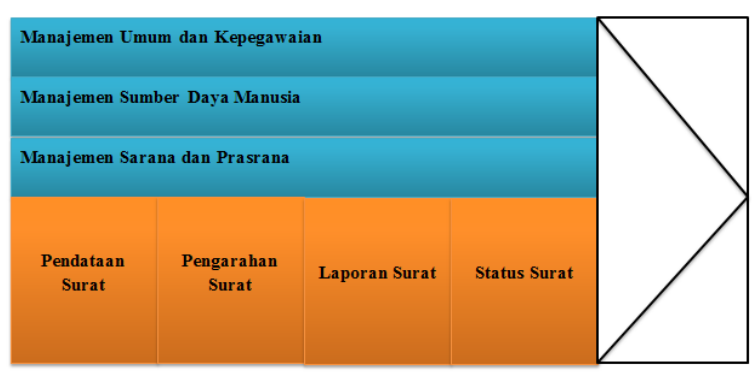

1) Mengidentifikasi tujuan bisnis ,tujuan bisnis biasanya dinyatakan dalam visi dan misi, kemudian bekerja dengan koordinasi, dibentuk desain hierarkis dan pembagian usaha, prinsip dan kapasitas untuk setiap posisi.

2) Mengidentifikasi proses bisnis, pada tahapan ini latihan-latihan yang diperlukan untuk mengenali semua ukuran bisnis yang diidentifikasikan dengan kerangka data yang 
akan dibuat. Dalam tahapan ini akan menguraikan kembali hasil dari analisis menggunakan teknik value chain agar lebih rinci.

3) Mengidentifikasi kelas data, Tahapan ini dilakukan untuk membedakan dan menggambarkan kelas data dalam membangun suatu kumpulan informasi. Hubungan antara kelas data dan ukuran bisnis diidentifikasi dengan huruf $\mathrm{C}, \mathrm{R}$, dan $\mathrm{U}$ untuk menunjukkan siklus mana yang menghasilkan (membuat) data, (membaca dengan teliti) dan menggunakannya (pelanggan). Hasilnya adalah sebagai berikut :

Tabel 2 Hubungan Kelas Data Dengan Proses Bisnis

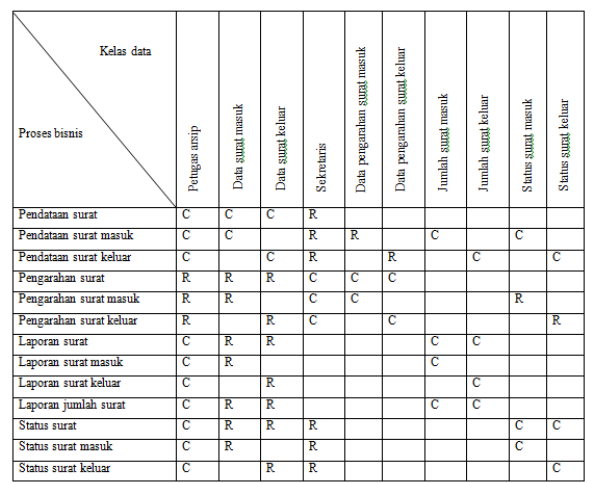

Tabel 3 Pengelompokan Proses Bisnis Dan Kelas Data

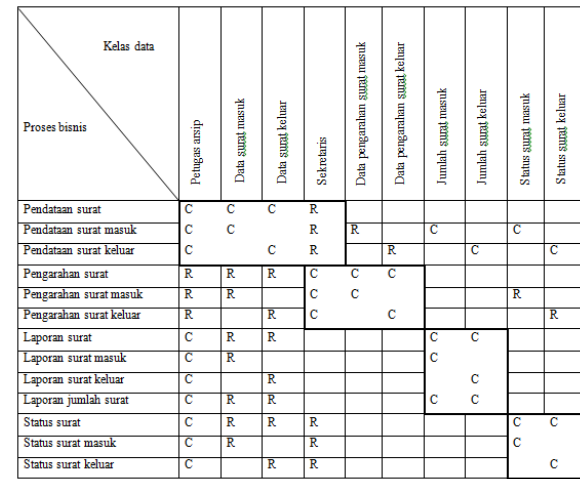

Selanjutnya menentukan aliran data dari proses bisnis.

Tabel 4 Aliran Data

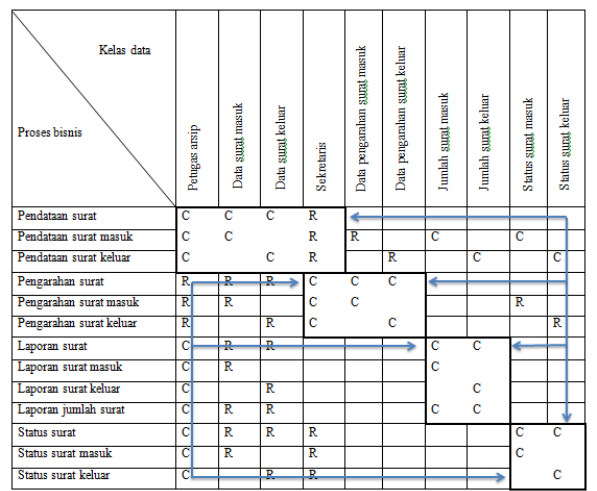

Kemudian, beri nama setiap kawasan bisnis terkait, berikan nama ini agar lebih mudah untuk mengklasifikasikan kelas data.

4) Mengidentifikasi Arsitektur Informasi adalah sebagai berikut :

Tabel 5 Hubungan Kelas Data Dengan Proses Bisnis

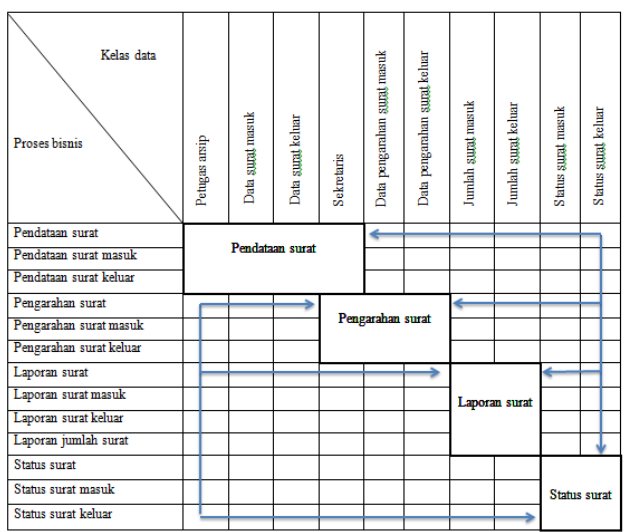

3.4. FEAF Level IV, Pada tahap ini, mengenali detail objek dari setiap model arsitektur, khususnya data, aplikasi, dan teknologi yang memanfaatkan matriks FEAF. Matriks FEAF membagi empat struktur menjadi 5 sudut pandang, khususnya sebagai berikut:

1) Perspektif Planner (Ruang lingkup)

- Kolom What (List of Business Object), Berisi informasi atau data yang diperlukan untuk perkembangan kapasitas bisnis.[6] hal-hal tersebut adalah sebagai berikut:

- Data Surat Masuk Yang diperlukan pada saat proses kegiatan pendataan surat masuk yaitu Form kartu kendali naskah dinas masuk yang berwarna Putih, Hijau dan Merah dan Lembar disposisi.

- Data Surat Keluar Data yang diperlukan pada saat proses kegiatan pendataan surat masuk yaitu Form kartu kendali naskah dinas keluar yang berwarna Putih, Kuning dan Merah dan Lembar ekspedisi.

- Laporan Surat Data yang diperlukan pada saat proses kegiatan laporan: yaitu Data jumlah surat masuk dan Data jumlah surat keluar.

- Kolom How ( List of Business Process ) berisi proses bisnis yang terjadi pada Dinas Perhubungan khususnya pada bagian pengelolaan surat. Adapun aktivitas-aktivitasnya sebagai berikut:

- Proses bisnis utama : pendataan surat, pengarahan surat, laporan surat dan status surat.

- Proses bisnis pendukung : Manajemen Umum dan Kepegawaian, Manajemen Sumber Daya Manusia (SDM), dan Manajemen Sarana dan prasarana.

- Kolom Where (List of Business Locations) berisi gambaran umum dan kondisi geografis 
yang terletak di Kantor Dinas Perhubungan Kab.Sukabumi yang beralamat di Jl.Raya Perintis Kemerdekaan Cikembang-Sukabumi.

2) Perspektif Owner ( Model Bisnis)

- Kolom What ( Semantic Model ) adalah semacam koneksi antara item penting yang tidak dikomunikasikan dengan gambar, namun dalam kata-kata yang digunakan untuk menggambarkan koneksi antar informasi dalam kumpulan data..[7]

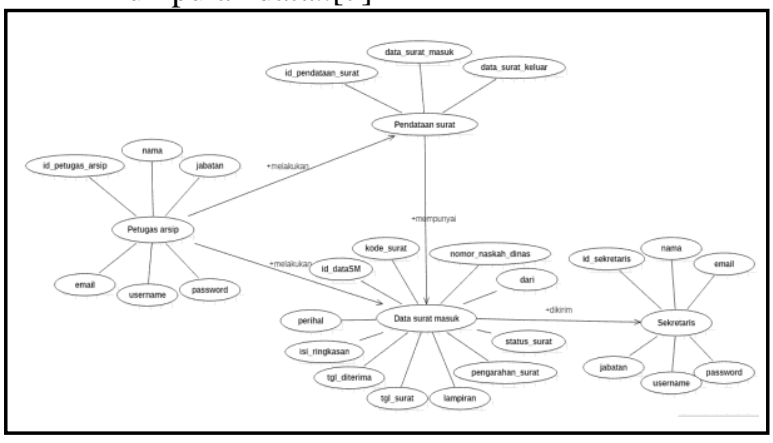

Gambar 5. Semantic Model Pendataan Surat

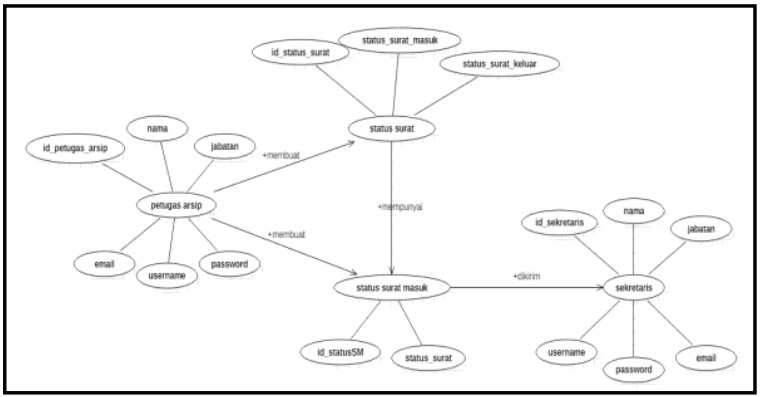

Gambar 6. Semantic Model Pengarahan Surat

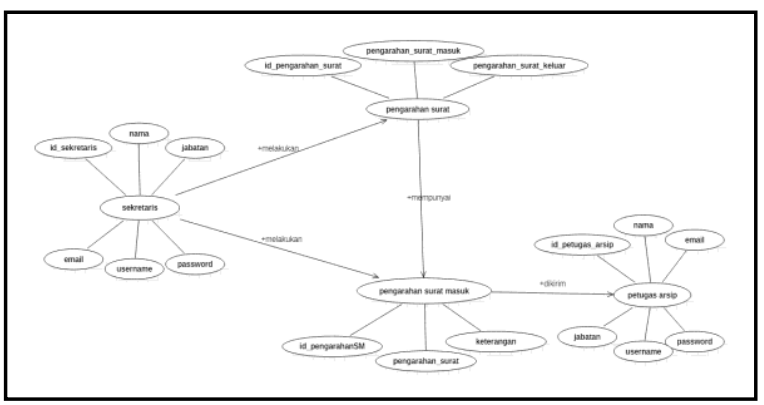

Gambar 7. Semantic Model Laporan Surat

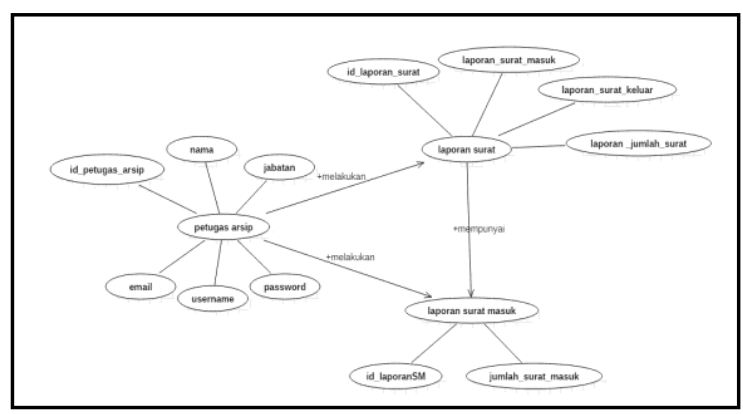

Gambar 8. Semantic Model Statu Surat

- Kolom How (Business Process Model )

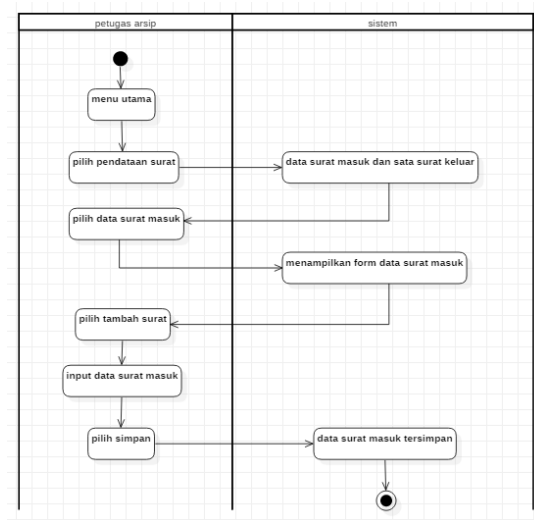

Gambar 9. Activity Diagram Pendataan Surat

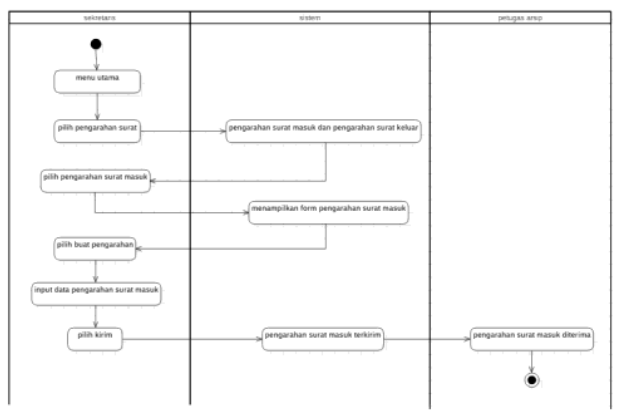

Gambar 10. Activity Diagram Pengarahan Surat

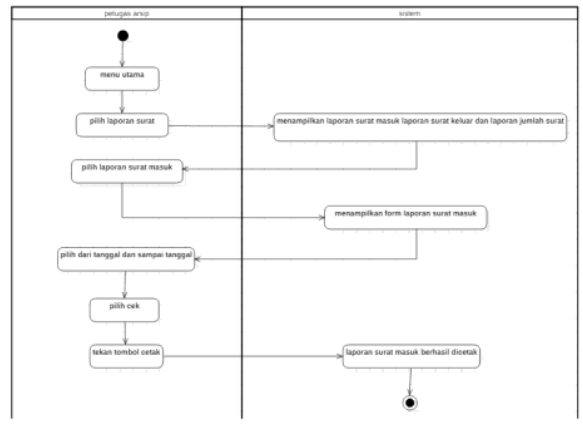

Gambar 11. Activity Diagram Laporan Surat

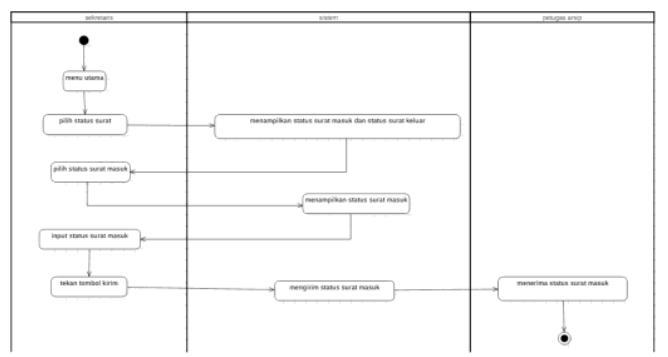

Gambar 12. Activity Diagram Status Surat

- Kolom Where ( Business Logistics System ) berisi penjelasan yang lebih rinci tentang lokasi 
yang digunakan dalam proses pengelolaan surat pada Dinas Perhubungan Kab.Sukabumi. Adapun beberapa aktivitas pengelolaan surat yang saya rancang yaitu pendataan surat, pengarahan surat,laporan surat dan status surat. Aktivitas - aktivitas tersebut dilakukan di Kantor Dinas Perhubungan Kabupaten Sukabumi, tepatnya di bagian Kasubag Umum dan Kepegawaian, yang bertanggung jawab dalam pengelolaan surat ini adalah bagian arsip yang terdiri dari 1 arsiparis dan 1 staf pegawai arsip dimana setiap kegiatan pengelolaan surat berkaitan dengan sekretaris.

3) Perspektif Designer (Model Sistem Informasi)

- Kolom What (Logical Data Model), berisi Entity Relationship Diagram adalah bentuk yang menggambarkan hubungan antara objekobjek data yang memiliki koneksi antar koneksi. Salah satunya adalah class diagram.[8] Adapun class diagram pengelolaan surat sebagai berikut

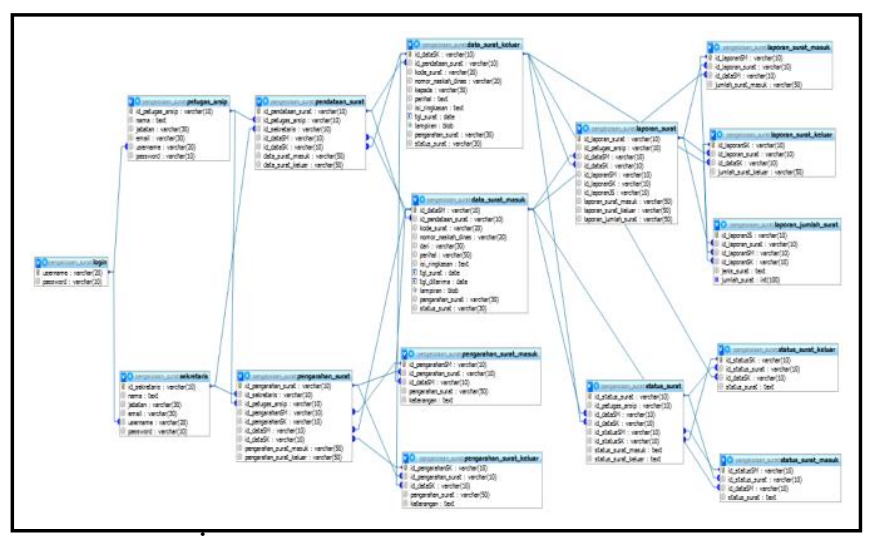

Gambar 13. Class Diagram

- Kolom Where (System Geographic Deployment Architecture), berisi rekayasa aplikasi yang menggambarkan kerangka data yang diusulkan yang akan digambarkan dalam sitemap di bawahnya

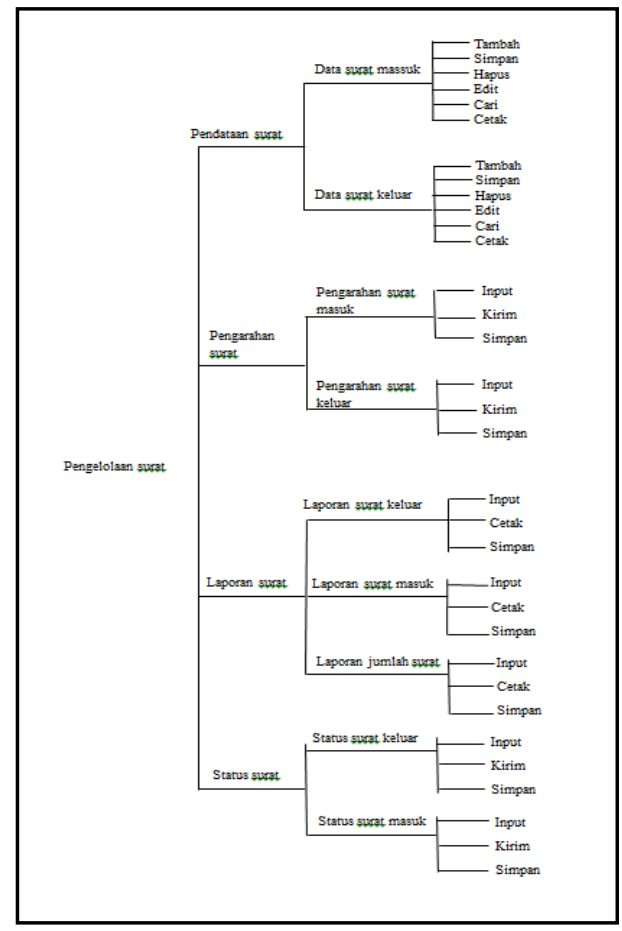

Gambar 14. Sitemap

- Kolom How (Application Architecture), berisi model yang masuk akal pada suatu instansi/organisasi dan digambarkan dalam arsitektur jaringan.[9] Model jaringan kerangka data eksekutif yang diusulkan oleh adalah sebagai berikut:

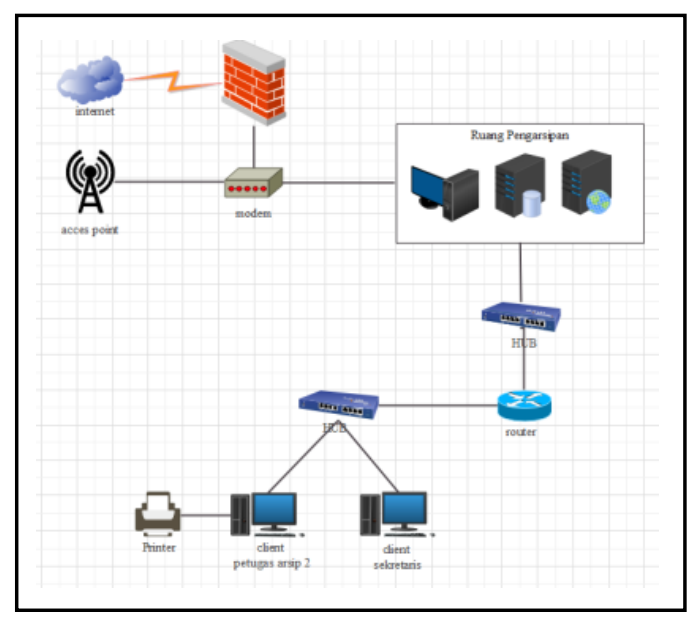

Gambar 15. Arsitektur Jaringan

4) Perspektif Builder Model Teknologi)

- Kolom What ( Physical Data Model ), berisi data model asli yang diharapkan sebagai tabel di samping properti yang akan digunakan untuk membuat kerangka kerja yang akan dibuat.

Tabel 6. Struktur Tabel Dalam Database

\begin{tabular}{|c|c|c|c|}
\hline Nama Tabel & Nama Field & Type Data & Lebar \\
\hline \multirow[t]{2}{*}{ Login } & Usename & Varchar & 10 \\
\hline & Password & Varchar & 10 \\
\hline \multirow[t]{6}{*}{ Petugas_arsip } & \begin{tabular}{|l} 
Id_petugas_arsip \\
\end{tabular} & Varchar & 10 \\
\hline & Nama & Text & 50 \\
\hline & \begin{tabular}{|l|} 
Jabatan \\
\end{tabular} & Varchar & 30 \\
\hline & Email & Varchar & 30 \\
\hline & \begin{tabular}{|l|} 
Username \\
\end{tabular} & Varchar & 20 \\
\hline & Password & Varchar & 10 \\
\hline \multirow[t]{6}{*}{ Selkretaris } & Id_sekretaris & Varchar & 10 \\
\hline & Nama & Text & 50 \\
\hline & Jabatan & Varchar & 30 \\
\hline & Email & Varchar & 30 \\
\hline & \begin{tabular}{|l|} 
Username \\
\end{tabular} & Varchar & 20 \\
\hline & \begin{tabular}{|l|} 
Password \\
\end{tabular} & Varchar & 10 \\
\hline \multirow[t]{3}{*}{ Pendataan_surat } & \begin{tabular}{|l|} 
Id_pendatagn_surat \\
\end{tabular} & Varchar & 10 \\
\hline & Data_surat_mas suk & Varchar & 50 \\
\hline & \begin{tabular}{|l} 
Data_surat_keluar \\
\end{tabular} & Varchar & 50 \\
\hline \multirow[t]{9}{*}{ Data_surat_masuk } & \begin{tabular}{|l|} 
Id_dataSM \\
\end{tabular} & Varchar & 10 \\
\hline & Kode_surat & Varchar & 20 \\
\hline & Nomor_naskah_dinas & Varchar & 20 \\
\hline & Dari & Varchar & 30 \\
\hline & \begin{tabular}{|l} 
Perihal \\
\end{tabular} & Varchar & 50 \\
\hline & Isi_ringkasan & Text & 100 \\
\hline & \begin{tabular}{|l|} 
Tgl_surat \\
\end{tabular} & Date & 15 \\
\hline & Tgl_diterima & Date & 15 \\
\hline & \begin{tabular}{|l|} 
Lampiran \\
\end{tabular} & Blob & 65.535 \\
\hline
\end{tabular}




\begin{tabular}{|c|c|c|c|}
\hline & Pengarahan_surat & Varchar & 30 \\
\hline & Status_surat & Varchar & 30 \\
\hline \multirow{11}{*}{ Data_surat_keluar } & \begin{tabular}{|l} 
Id_dataSK \\
\end{tabular} & Varchar & 10 \\
\hline & Kode_surat & Varchar & 20 \\
\hline & Nomor_naskah_dinas & Varchar & 20 \\
\hline & Kepada & Varchar & 30 \\
\hline & Perihal & Varchar & 50 \\
\hline & Isi_ringkasan & Text & 100 \\
\hline & Tgl_surat & Date & 15 \\
\hline & Tgl_diterima & Date & 15 \\
\hline & Lampiran & Blob & 65.535 \\
\hline & Pengarahan_surat & Varchar & 30 \\
\hline & Status_surat & Varchar & 30 \\
\hline \multirow[t]{3}{*}{ Pengarahan_surat } & Id_pengarahan & Varchar & 10 \\
\hline & Pengarahan_SM & Varchar & 50 \\
\hline & Pengarahan_SK & Varchar & 50 \\
\hline \multirow[t]{3}{*}{ Pengarahan_surat_masuk } & Id_pengarahanSM & Varchar & 10 \\
\hline & Pengarahan_surat & Varchar & 50 \\
\hline & Keterangan & Text & 50 \\
\hline \multirow[t]{3}{*}{ Pengarahan_surat_keluar } & Id_pengarahanSK & Varchar & 10 \\
\hline & \begin{tabular}{|l} 
Pengarahan_surat \\
\end{tabular} & Varchar & 50 \\
\hline & Keterangan & Text & 50 \\
\hline \multirow[t]{4}{*}{ Laporan_surat } & \begin{tabular}{|l} 
Id_laporan_surat \\
\end{tabular} & Varchar & 10 \\
\hline & Laporan_surat_masulk & Varchar & 50 \\
\hline & Laporan_surat_keluar & Varchar & 50 \\
\hline & Laporan_jumlah_surat & Varchar & 50 \\
\hline Laporan_surat_masuk & Id_laporanSM & Varchar & 10 \\
\hline
\end{tabular}

\begin{tabular}{|l|l|c|c|}
\hline & Jumlah_surat_masul & Varchar & 50 \\
\hline Laporan_surat_keluar & Id_laporanSK & Varchar & 10 \\
\hline & Jumlah_surat_keluar & Varchar & 50 \\
\hline Laporan_jumlah_surat & Id_laporanIS & Varchar & 10 \\
\hline & Jenis_surat & Text & 50 \\
\hline & Jumlah_surat & Varchar & 100 \\
\hline Status_surat & Id_status_surat & Varchar & 10 \\
\hline & Status_surat_masuk & Text & 50 \\
\hline & Status_surat_keluar & Text & 50 \\
\hline Status_surat_masuk & Id_statusSM & Varchar & 10 \\
\hline & Status_surat & Text & 50 \\
\hline Status_surat_keluar & Id_statusSK & Varchar & 10 \\
\hline & Status_surat & Text & 50 \\
\hline
\end{tabular}

- Kolom How ( System Design ), berisi informasi yang akan disusun dan hasil yang akan dibuat oleh framework mengenai rinciannya akan dijelaskan pada tabel terlampir:

Tabel 7. Input Output Usulan Sistem Informasi

\begin{tabular}{|c|c|c|c|c|}
\hline $\begin{array}{l}\text { Nama Sistem } \\
\text { Informasi }\end{array}$ & Sub Proses & Tnput & Output & Ket. \\
\hline \multirow[t]{3}{*}{$\begin{array}{l}\text { Sistem } \\
\text { Informasi } \\
\text { Pengelolaan } \\
\text { Surat }\end{array}$} & $\begin{array}{l}\text { Pendataan } \\
\text { surat }\end{array}$ & $\begin{array}{l}\text { Form data } \\
\text { surat masuk } \\
\text { dan form } \\
\text { data surat } \\
\text { keluar }\end{array}$ & $\begin{array}{l}\text { Data surat } \\
\text { masuk dan } \\
\text { data surat } \\
\text { keluar }\end{array}$ & $\begin{array}{l}\text { Mengelola dan } \\
\text { mendata surat masuk: } \\
\text { dan surat kehux }\end{array}$ \\
\hline & $\begin{array}{l}\text { Pengarahan } \\
\text { surat }\end{array}$ & $\begin{array}{l}\text { Form } \\
\text { pengarahan } \\
\text { surat masuk } \\
\text { dan surat } \\
\text { keuar }\end{array}$ & $\begin{array}{l}\text { Data } \\
\text { pengarahan } \\
\text { surat masuk } \\
\text { dan surat } \\
\text { keluar }\end{array}$ & $\begin{array}{l}\text { Pengarahan surat } \\
\text { dilakukan ketika ada } \\
\text { transalssi surat } \\
\text { masuk maupun surat } \\
\text { keluar dan yang } \\
\text { berhak melakukan } \\
\text { pengarahan surat } \\
\text { yaitu sekretaris. }\end{array}$ \\
\hline & $\begin{array}{l}\text { Laporan } \\
\text { surat }\end{array}$ & $\begin{array}{l}\text { Form laporn } \\
\text { surat masuk } \\
\text { laporan sura } \\
\text { keluar dan } \\
\text { laporan } \\
\text { jumlah surat }\end{array}$ & \begin{tabular}{|l|} 
Data \\
jumlah \\
surat \\
masuk, data \\
surat kelux \\
dan jumlah \\
keselurihan \\
data surat \\
\end{tabular} & $\begin{array}{l}\text { Mengelola jumlah } \\
\text { data surat masukdan } \\
\text { data surat kelux } \\
\text { untuk dilabukan nya } \\
\text { pelaporan jumlah } \\
\text { data surat setiap } \\
\text { tahunnya. }\end{array}$ \\
\hline
\end{tabular}

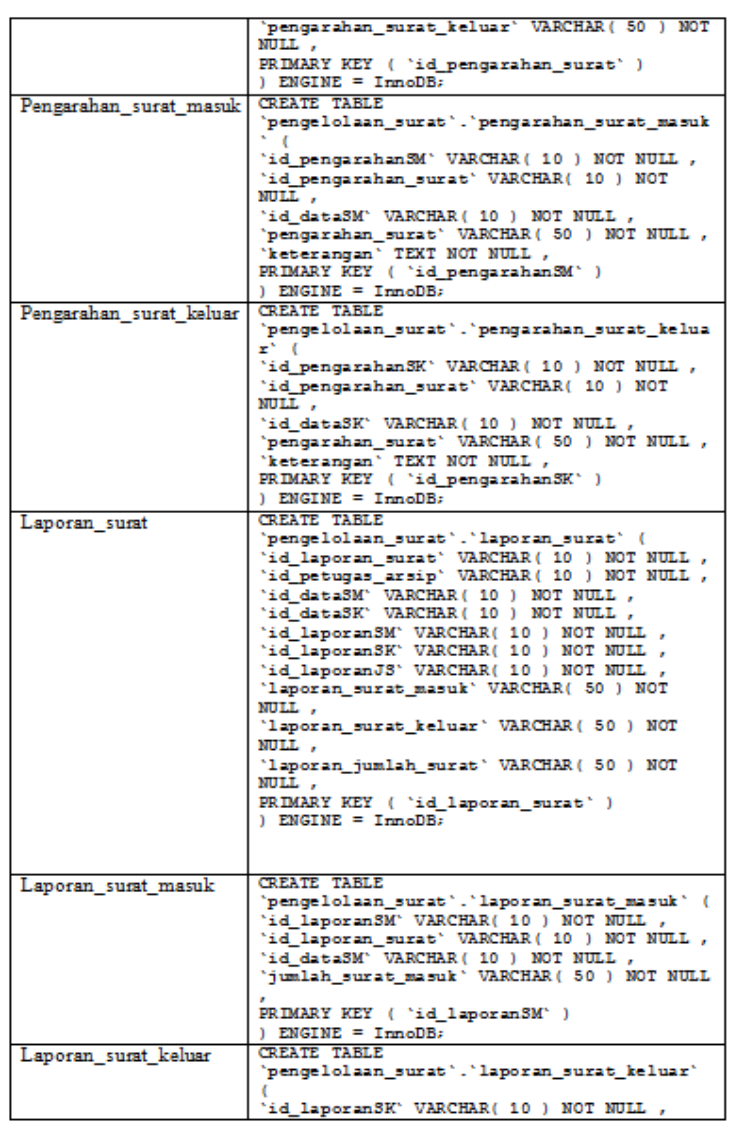

- Kolom Where (Technology architecture ), memberikan gambaran teknologi yang dibutuhkan di Kantor Dinas Perhubungan Kabupaten Sukabumii, yang diperlukan adanya perangkat keras (hardware), perangkat lunak (software) dan sistem operasi.[10] Rincian dari kebutuhan tersebut yaitu server, client, HUB, router, acces point dan koneksi internet.

5) Perspektif Subcontractor (Spesifikasi Detail)

- Kolom What (Data Definition), berisi Data Definition Language (DDL) yang merupakan perintah untuk digunakan dalam membuat maupun memodifikasi struktur dari suatu objek dalam data-base yang utamanya berbentuk skema.[11]

Tabel 8.Data Definition Language dalam Struktur Tabel

\begin{tabular}{|c|c|}
\hline Nama Tabel & Data Definition Language \\
\hline Login & 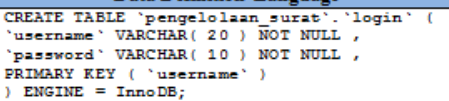 \\
\hline Petugas_arsip & 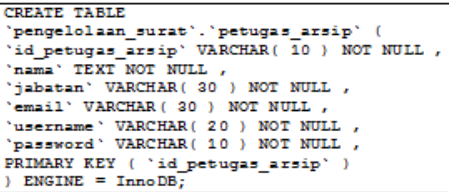 \\
\hline Sekretaris & 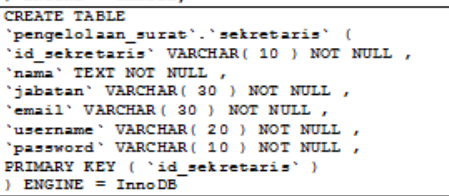 \\
\hline Pendataan_surat & 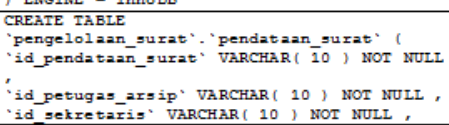 \\
\hline
\end{tabular}




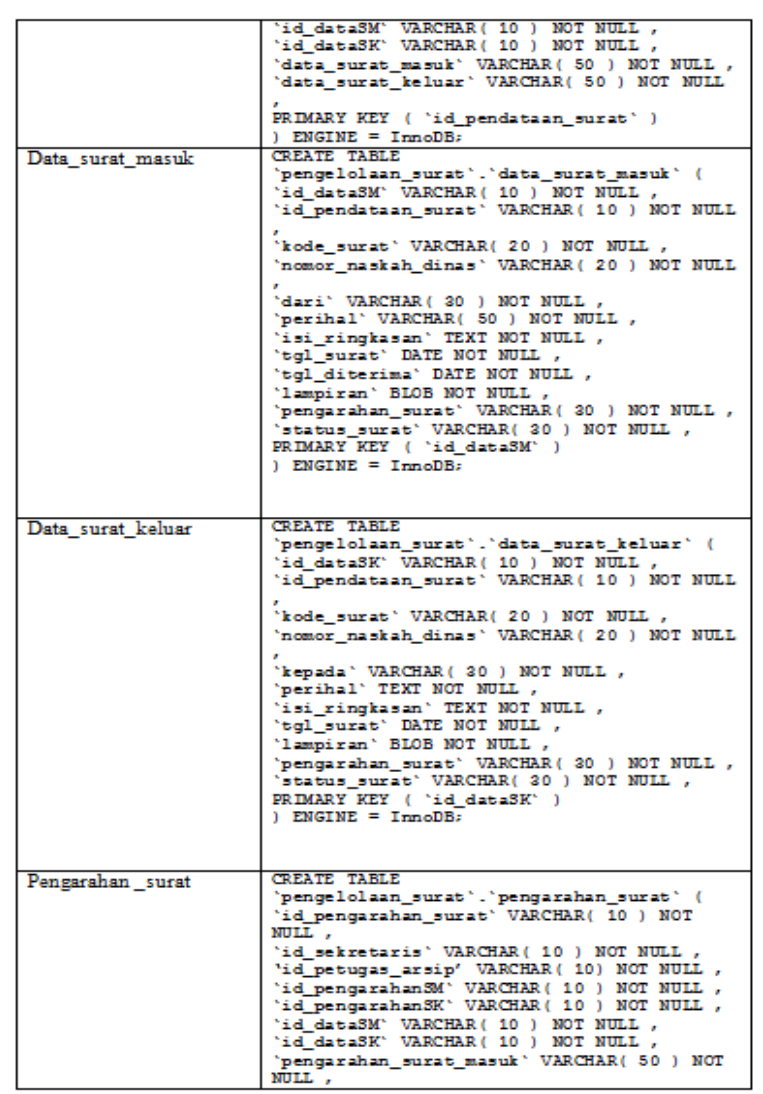

\begin{tabular}{|c|c|}
\hline & 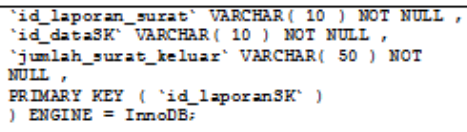 \\
\hline Laporan_jumlah_surat & 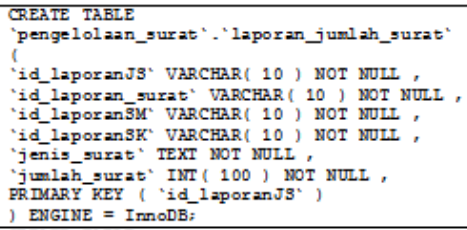 \\
\hline Status_surat & 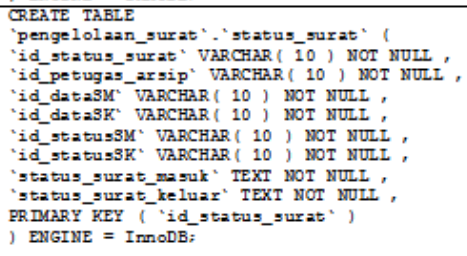 \\
\hline Status_surat_masuk & 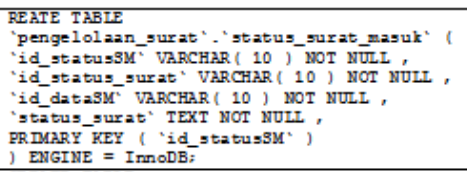 \\
\hline Status_surat_keluar & 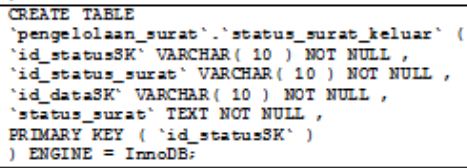 \\
\hline
\end{tabular}

6) Kerangka Kerja (Blue Print) Arsitektur)

Blueprint (cetak biru) arsitektur diperoleh dari hasil pemodelan dan analisis kinerja teknologi informasi. [12] Perolehan cetak biru tersebut diharapkan mampu memberikan hasil yang maksimal dalam perancangan enterprise architecture pada pengelolaan surat yang ada di Dinas Perhubungan Kabupaten Sukabumi. Adapun hasilnya sebagai berikut :

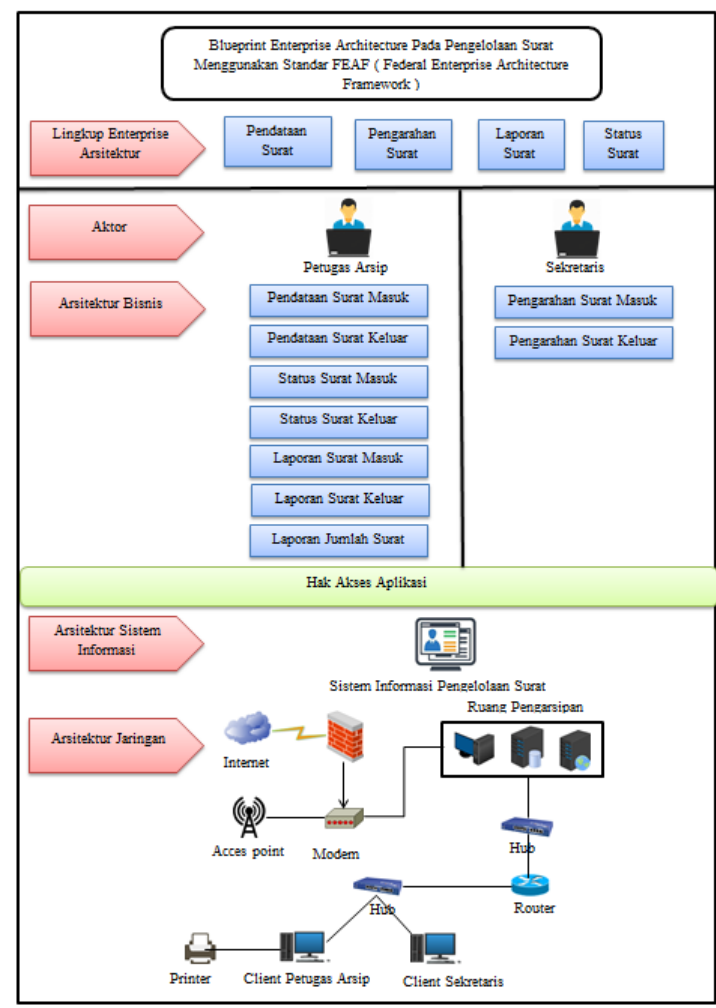

Gambar. 16. Blueprint Perancangan Enterprise Architecture Pengelolan Surat Pengelolan Surat.

\section{Kesimpulan}

Berdasarkan penelitian yang sudah dilakukan oleh penulis maka, dapat dilihat dari Gambar 1 Grafik Data Surat Masuk secara garis besar terjadi kehilangan data surat masuk di tahun 2019 sekitar $50 \%$, sedangkan di Gambar 2 Grafik Data Surat Keluar terjadi kesalahan dalam pencatatan surat itu terjadi hampir setiap tahun dan mencapai $10-40 \%$. Dengan adanya hal tersebut maka ditarik kesimpulan yaitu peneliti membuat Perancangan Enterprise Architecture Pada Pengelolaan Surat yang menggunakan standar FEAF ( Federal Enterprise Architecture Framework ) dimana model FEAF ini bisa digunakan untuk perencanaan strategis sistem informasi dan dapat digunakan untuk pengembangan suatu architectur yang lebih baik. Dari penelitian tersebut maka menghasilkan sebuah kerangka kerja ( blueprint ) yang terdiri dari lingkup enterprise architecture, aktor, architecture bisnis, architecture sistem informasi, dan architecture teknologi dalam segi architecture jaringan. Kerangka kerja (blueprint) yang dihasilkan dapat dijadikan acuan untuk membuat dan mengembangkan teknologi informasi yang sesuai dengan tujuan Dinas Perhubungan Kab.Sukabumi, serta dapat dijadikan sebagai landasan atau panduan dalam mengimplementasikan sistem pengelolaan surat di Dinas Perhubungan Kab.Sukabumi. 


\section{Daftar Pustaka}

[1] C. Kurnia Sastradipraja, D. Gustian, and S. D. Antadipura, "Perencanaan Strategi Sistem Informasi Penjualan Menggunakan Pendekatan Togaf Adm (Studi Kasus : Three Sister's House Of Beauty)," vol. 04, no. 2019, pp. 8-11, 2020, doi: 10.34010/aisthebest.v4i02.2332.

[2] N. Azizah, E. S. Aisyah, and R. Taemima, "Perancangan Sistem Informasi Pengarsipan Data-Data Produksi Pada Pt. Kuralon Indah Sejahtera," SENSI J., vol. 5, no. 1, pp. 1222, 2019, doi: 10.33050/sensi.v5i1.225.

[3] S. J. Nugroho, "Enterprise Architecture Planning Sistem Informasi Rsia Andini Dengan Menggunakan Togaf," pp. II-4, 2012.

[4] M. Defriani and M. Gito Resmi, "Analisis Arsitektur E-government dengan Menggunakan Kerangka Kerja Federal Enterprise Architecture ( FEA )," Konf. Nas. SNIA 2019, vol. 3, no. 2, pp. 1-16, 2019.

[5] R. Yunis and Theodora, "Penerapan Enterprise Architecture Framework Untuk Pemodelan Sistem Informasi," JSM STMIK Mikroskil, vol. 13, no. 2, pp. 159-168, 2016.

[6] M. Feaf and K. Sukabumi, "Perancangan Enterprise Architecture Pendaftaran Uji Kir," vol. 2020, no. Semnasif, 2020.

[7] A. Saputra, "Perancangan Basis Data," Penerbit Andi, Yogyakarta, vol. 4, no. 3, pp. 448-457, 2007, [Online]. Available: http://andipublisher.com/produk- 0701002341-perancangan-basis-data.html.

[8] M. H. Alfarisy and A. Diana, "Rancang Bangun Sistem Informasi Penyewaan Mobil pada Abu Sulaiman Rent Car," Semin. Rekayasa Teknol., pp. 320-329, 2018.

[9] I. D. Ayu and E. Yuliani, "Penerapan Zachman Framework dalam Merancang Customer Relationship Management pada Bank Perkreditan Rakyat Implementation of Zachman , s Framework in Designing Customer Relationship Management at Bank Perkreditan Rakyat," J. Ilm. Sisfotenika, vol. 8, no. 1, pp. 93-104, 2018.

[10] R. Irfanto and J. Fernandes Andry, "1 Perancangan Enterprise Architecture Menggunakan Zachman Framework (Studi Kasus: Pt.Vivamas Adipratama)," Peranc. Enterp. Archit. Menggunakan Zachman Fr, no. November, pp. 1-2, 2014.

[11] D. Puspitasari, Y. Watequlis, and R. A. Asmara, "Penggunaan Tansact SQL (T-SQL) Pada Pengembangan Aplikasi Manajemen Basis Data Berbasis Web," J. Simantec, vol. 6, no. Desember, p. 8, 2017.

[12] L. Retnawati, "Perancangan Enterprise Architecture Menggunakan TOGAF di Universitas ABC," J. IPTEK, vol. 22, no. 1, p. $13, \quad 2018, \quad$ doi: 10.31284/j.iptek.2018.v22i1.221. 